\title{
The Prohibition on Abortion Counseling and Referral in Federally-Funded Family Planning Clinics
}

\author{
C. Andrew McCarthy†
}

In this comment, the author argues that federal regulations barring payment of title $X$ funds to clinics that counsel clients about abortion and make abortion referrals impose an unconstitutional restriction on the clinics' free speech rights. He then maintains that the unconstitutional conditions doctrine currently applied by the courts is based on a fallacious distinction between a penalty and a subsidy and should be revised. The author proposes that the doctrine be changed to prohibit the government from using a conditional grant to suppress indirectly the exercise of a constitutional right that it could not suppress directly.

\section{INTRODUCTION}

The United States Supreme Court reshaped the abortion debate in its July 1989 decision, Webster v. Reproductive Health Services, ${ }^{1}$ which upheld a Missouri statute that prohibited public employees froin performing nontherapeutic abortions and barred the use of public facilities for abortions. ${ }^{2}$ The Webster Court held that the right to an abortion receives little protection under the federal Constitution, and implied that that any "reasonably designed"3 abortion regulation that "permissibly

$\dagger$ B.A. 1981, Brown University; J.D. 1989, Boalt Hall School of Law, University of California, Berkeley. I would like to thank Professor Herma Hill Kay, Alison Keel, Mareta Hamre, Ellen Kaulbach, Clare Maier, Betsy McCarthy, and Sarah McCarthy for their guidance and assistance in preparing this Comment for publication. I also benefitted enormously from the briefs of the parties in two abortion cases that were litigated in 1988. See infra notes 1 \& 18 . I thank attorneys Susan Lauscher, and Roger Evans, Deputy Assistant Secretary for Population Affairs Nabers Cabaniss, and the Office of the Missouri Attorney General for sending me the briefs.

1. 109 S. Ct. 3040 (1989).

2. Four justices indicated that they are now prepared to overrule Roe v. Wade, 410 U.S. 113 (1973). In October Term, 1989, the Court will hear three cases, any one of which could become a vehicle to overrule Roe. See Ohio v. Akron Center for Reproductive Health, prob. juris. noted, 109 S. Ct. 3239 (1989) (challenge to law requiring that one of teenager's parents be notified before she can obtain an abortion); Hodgson v. Minnesota, cert. granted, 109 S. Ct. 3240 (1989) (requiring both parents be notified); Turnock v. Ragsdale, hearing granted, 109 S. Ct. 3239 (1989) (requiring clinics performing first trimester abortions to provide the same facilities as a hospital).

3. Webster, 109 S. Ct. 3058. 
furthers the State's interest in protecting human life"4 would be constitutional. Although Webster reaffirmed government's broad power to favor childbirth over abortion in its allocation of public resources, ${ }^{5}$ it left open the question on which this Comment focuses-whether a prohibition on abortion counseling and referral in publicly funded family planning clinics violates the first amendment. ${ }^{6}$

In the spring of 1988, the Department of Health and Human Services (HHS) promulgated regulations ${ }^{7}$ that reinterpreted various provisions of the Public Health Service Act. ${ }^{8}$ The new regulations bar family planning clinics ${ }^{9}$ that receive federal funds from counseling clients about abortion, making abortion referrals, or lobbying for the pro-choice position. ${ }^{10}$ The potentially coercive nature of these allocational sanctions should concern men and women on both sides of the abortion debate.

This Comment summarizes these regulations, reviews their background, and considers their constitutionality in light of the unconstitu-

4. Id. at 3057. In his dissent, Justice Blackmun accused the Court of adopting "nothing more than a dressed-up version of rational-basis review, this Court's most lenient level of scrutiny." Id. at 3076. He called this approach "wholly incompatible with the fundamental right recognized in Roe ...." Id. at 3076 n.10 (quoting Akron v. Center for Reproductive Health, Inc., 462 U.S. 416, 420 n.1 (1982)).

5. Id. at 3052 .

6. The Missouri statute forbade public employees from engaging in abortion counseling in the course of their employment and barred such speech in public facilities. A majority of the Court accepted Reproductive Health Service's argument that the challenge to the statutc's counseling prohibition was moot. Id. at 3053. Consequently, the Court never reached the first amendment question, as applied to the states via the fourteenth amendment.

7. Amendments of Subpart A of Part 59, 53 Fed. Reg. 2944-46 (1988) (codified at 42 C.F.R. $\$ \S 59.2-59.10$ (1988)) [hereinafter cited by C.F.R. section only].

8. Public Health Service Act, codified in pertinent part at 42 U.S.C. $\$ \S 300-300 a-7$ (1982). Title X of the Family Planning and Services and Population Research Act of 1970 authorizes HHS "to make grants and to enter into contracts with public or nonprofit private entities to assist in the establishment and operation of voluntary family planning projects which shall offer a broad range of acceptable and effective family planning methods and services."

9. For convenience, "clinics" refers to the clinics themselves as corporate entities with their own first amendment rights and to the health care providers who work at the clinics. $C f$. Consolidated Edison Co. v. Public Serv. Comm'n, 447 U.S. 530 (1980) (recognizing utility's right of free speech).

10. The HHS regulations are not the same as the Adolescent Family Life Act of 1981, 42 U.S.C. $\$ \S 300 z-300 z-10$ (1982 \& Supp. IV 1986) [hereinafter AFLA], but the AFLA has similar provisions. Under the AFLA, providers of adolescent pregnancy prevention programs receiving grant money may not provide abortion counseling and referral, unless the pregnant teenager and her parents request referral to an agency that provides abortion counseling. Id. $\S 300 \mathrm{z}-10$ (a). The Supreme Court applied conventional establishment clause doctrine in upholding the AFLA in Bowen v. Kendrick, 108 S. Ct. 2562 (1988) (plurality opinion). See Note, Leading Cases, 102 HARv. L. REV. 143, 211-22 (1988).

In addition to the AFLA, the Foreign Assistance Act of 1961, codified as amended at 22 U.S.C. $\S 2151 \mathrm{~b}(f)(1)(1982)$, has been administratively interpreted to prohibit federally funded overseas clinics from telling pregnant clients that abortion is an available option. See Benshoof, The Chastity Act: Government Manipulation of Abortion Information and the First Amendment, 101 HARv. L. REV. 1916, 1917 n.8, 1919 n.21 (1988). 
tional conditions doctrine. It examines and proposes changes to the unconstitutional conditions doctrine. It then analyzes the HHS regulations under its proposed unconstitutional conditions doctrine and concludes that the HHS regulations violate the first amendment by imposing an unconstitutional content-based penalty on the exercise of the clinics' free speech rights.

\section{I}

\section{Legislative History AND SUMMaRY OF THE REGULATIONS}

Title X of the Public Health Service Act authorizes grants to profit and nonprofit organizations "to assist im the establishment and operation of voluntary family planning projects" that give priority to low income families. ${ }^{11}$ Title $X$ serves about $4,300,000$ poor women annually tlirough some 4000 family planning clinics which receive $\$ 140$ million in title $X$ grants. ${ }^{12}$ Several types of entities receive title $X$ funds: $40 \%$ are state, city, and mumicipal public health departments; $28 \%$ are Planned Parenthood clinics; the remaming $32 \%$ are hospitals and other community health organizations. ${ }^{13}$ The grants are subject to the regulations tliat the HHS Secretary promulgates. ${ }^{14}$

Section 1008 of title X, passed in 1970, states that "[n]one of the funds appropriated under this title shall be used in programs where abortion is a method of family planning." 15 In 1988, the HHS Secretary read this prohibition very broadly and promulated regulations prohibiting abortion counseling and lobbying by title $\mathrm{X}$ projects and requiring that any non-title $X$ project that offers such services be pliysically separate from the title $X$ project. Under these rules a family planning program will lose its title $\mathrm{X}$ funds "unless it provides assurances satisfactory to the

11. 42 U.S.C. $\S 300$ (a) (1982 \& Supp. IV 1986).

12. N.Y. Times, July 31, 1987, at A1, col. 1. For slightly different estimates of title X's scope, see 131 Cong. REC. S16860 (daily ed. Dec. 4, 1985) (for 1984, \$139 million distributed to 4,500 clinics serving 3.9 million persons).

13. 131 Cong. ReC. S16860 (daily ed. Dec. 4, 1985). This Comment considers the constitutionality of the new HHS regulations from the viewpoint of private nonprofit health care providers like Planned Parenthood.

14. 42 U.S.C. $\S 300 a-4$ (a) (1982). In addition to the prohibition on "programs where abortion is a method of family planning," the Act contains other abortion-related provisions. One allows medical personnel and facilities with moral objections to abortion and sterilization to refuse to perform those procedures without jeopardizing their title X funds. Grantees may not discriminate among their employees based on the employees' attitudes toward abortion. Grantees must treat equally personnel who perform lawful abortions outside the title $\mathrm{X}$ project and personnel who refuse to perform them for religious reasons. 42 U.S.C. $\$ 300 \mathrm{a}-7$ (b)-(e) (1982). Criminal sanctions exist for grantees or government officials who coerce women to undergo abortions by threatening them with loss of their welfare benefits. Id. $\S 300 \mathrm{a}-8$.

15. Public Health Service Act, Pub. L. 91-572, § 1008, 84 Stat. 1508 (codified at 42 U.S.C. § 300a-6 (1970)) [hereinafter section 1008]. 
[HHS] Secretary that it does not include abortion as a method of family planning."16

These regulations represent a sharp break with nearly twenty years of administrative interpretation of section 1008, an interpretation to which Congress apparently acquiesced ${ }^{17}$ through its continued appropriation of title X funds. ${ }^{18}$ Until 1988, HHS had allowed clinics to offer abortion counseling to their pregnant clients. ${ }^{19}$ The 1981 HHS Program Guidelines, ${ }^{20}$ for example, instructed clinics to offer pregnant women "non-directive counseling" on prenatal care, infant care, adoption, and "pregnancy termination." 21

Since the passage of section 1008 in 1970, Congress has rejected various proposals that would have barred clinics from using title $\mathrm{X}$ funds for abortion referral services. A 1974 amendment, which the House voted down by a two-to-one margin, sought to ban use of title $\mathrm{X}$ funds for abortion referral services. ${ }^{22}$ The following year, the House voted down an amendment that would have forbidden title $\mathrm{X}$ grantees to "promote or encourage the practice of abortion."23 In 1978, the House explicitly rejected a statutory amendment similar to the new HHS regulations when members defeated an amendment that would have barred title $\mathrm{X}$ grants to entities that "directly or indirectly provide[] abortion, abortion counselimg, or abortion referral services." 24

A more recent refusal to strengthen the anti-abortion language of section 1008 came in 1985. The House Energy and Commerce Committee reaffirmed verbatim the language of the 1970 conference committee

16. 42 C.F.R. $\$ 59.7$ (1988).

17. See Bob Jones Univ. v. United States, 461 U.S. 574, 599-601 (1983) (congressional inaction with respect to vigorously debated social issues indicates acceptance of existing administrative interpretations).

18. See, e.g., H.R. ReP. No. 498, 100th Cong., 1st Sess. 275, 275-287 (1987). This Comment does not address in detail the administrative law issues that the regulations present, but it does briefly review their legislative history.

More detailed legislative histories and analyses of the administrative law issues are available in the four published opinions dealing with the regulations: New York v. Bowen, 690 F. Supp. 1261 (S.D.N.Y.), aff'd without opinion, 863 F.2d 46 (2d Cir. 1988), cert. denied sub nom. Williams v. New York, 109 S. Ct. 3255, aff'd on rehearing sub nom. New York v. Sullivan, 889 F.2d 401 (2d Cir. 1989); Massachusetts v. Bowen, 679 F. Supp. 137 (D. Mass. 1988), aff'd sub nom, Massachusetts v. Secretary of Health and Human Servs., 873 F.2d 1528 (Ist Cir. 1989); Planned Parenthood Fed'n of America v. Bowen, 680 F. Supp. 1465 (D. Colo. 1988).

19. 53 Fed. Reg. 2922-23 (1988); Bowen, 690 F. Supp. at 1269 (quoting internal HHS memoranda that asserted a counselor's duty to disclose all legal pregnancy options, although the counselor "should not employ directive counseling in relation to abortions").

20. Quoted in Bowen, 690 F. Supp. at 1270.

21. Id. Section 1008 was held not to bar title $\mathrm{X}$ clinics from making referrals for medically necessary abortions. Valley Family Planning v. North Dakota, 661 F.2d 99, 101 (8th Cir. 1981).

22. 120 CONG. REC. $21,687-95$ (1974).

23. 121 CONG. REC. 20,863-65 (1975).

24. 124 CONG. REC. 37,045 (1978). 
report stating that section 1008 is not meant to interfere with abortionrelated services that are funded at the state and local levels. ${ }^{25}$ In 1987 , three bills designed to end abortion counseling and referral under title $X$ were not voted out of committee. ${ }^{26}$

Despite findings that the clinics were complying with title $\mathrm{X},{ }^{27} \mathrm{HHS}$ promulgated the new regulations in 1987 . The agency put forth several rationales for the changes. First, HHS stated that new regulations were necessary to "administer [title X] as provided by Congress"28 and to "faithfully and effectively maintain" section 1008's prohibition on the use of abortion as a method of family planning. ${ }^{29}$ HHS also contended that

25. H.R. ReP. No. 159, 99th Cong., 1st Sess. 6-7 (1985), (quoting H.R. Conf. ReP. No. 911667, 91st Cong., 2d Sess. 8-9 (1970)).

26. President's Pro-Life Bill of 1987, S. 1242, 100th Cong., 1st Sess. (1987); Unborn Children's Civil Rights Act, S. 381, 100th Cong., 1st Sess. (1987); Preborn Children's Civil Rights Act of 1987, H.R. 720, 100th Cong., 1st Sess. (1987).

27. HHS Secretary Heckler was satisfied that the title $\mathrm{X}$ grantees "have been very aware and have honored the law in terms of the abortion prohibition. ..." Reauthorization of Title; Family Planning Program: Hearings Before the Subcomm. on Health and the Environment of the House Comm. on Energy and Commerce, 98th Cong., 2d Sess. 472 (1984) (statement of Margaret M. Heckler, Secretary, Dept. of Health and Human Services). The General Accounting Office (GAO) similarly found that grantces were not using title $X$ funds to perform or to advocate abortions. Comp. Gen. Rep. No. GAO-HRD-82-106 (1982), quoted in Massachusetts v. Bowen, 679 F. Supp. 137, 142 (D. Mass. 1988), aff'd sub nom. Massachusetts v. Secretary of Health and Human Servs., 873 F.2d 1528 (1st Cir. 1989).

28. 53 Fed. Reg. 2923 (1988). One Congressman aceused HHS of distorting his statements in the 1970 floor debate when the agency reviewed the legislative history in the preamble to the 1988 regulations. 53 Fed. Reg. 2944 (1988). In determining Congressional intent, HHS heavily stressed Representative Dingell's remark that "committee members clearly intend that abortion is not to be encouraged or promoted in any way through [title X]." 116 CONG. REC. 37375 (1970) (statement of Rep. Dingell). Representative Dingell repudiated that remark in a stinging 1987 letter to HHS Secretary Bowen. He protested "in the strongest possible terms" the "very narrow" and "biased interpretation of congressional intent" in HHS's preamble to the new regulations. Representative Dingell stated that the 1970 floor debate was quoted out of context: "The [1970] statement did not suggest, either expressly or implicitly, that family planning clinics should be prohibited from counseling pregnant women on any matter or referring them to appropriate facilities." Letter from Rep. John D. Dingell to HHS Secretary Otis Bowen (Oct. 14, 1987), quoted in Brief for Appellant at app., Massachusetts v. Bowen, 873 F.2d 1528 (1st Cir. 1989).

The Conference Report clearly left open the possibility that grantees who facilitated abortions would not automatically lose their federal funds. While section 1008 was inserted to make clear Congress' intent to prevent title $X$ funds from being used for abortion, "[t]he legislation does not and is not intended to interfere with or limit programs conducted in accordance with state or local laws and regnlations which are supported by funds other than those authorized under this legislation." H.R. CONF. REP. No. 1667, 91st Cong., 2d Sess. (1970), reprinted in 1970 U.S. CODE CoNG. \& ADMIN. NEwS 5080-82.

29. 53 Fed. Reg. 2923 (1988). It is not at all clear what Congress meant by "family planning." The Senate Committee stated in its report that family planning is not "merely a euphemism for birth control," but involves "medieal services, including consultation, examination, prescription, and continuing supervision, supplies, instruction, and referral to other medical services as needed." $S$. REP. No. 1004, 91 st Cong., 2d Sess. 10 (1970). The Conference Report stated that the title X funds were to be used only for "preventive family planning services ... and other related medieal, informational, and educational activities. The conferees have adopted the language contained in section 1008 , which prohibits the use of such funds for abortion, in order to make clear this intent." 
the existing guidelines did not offer clear guidance to the clinics on "how to preserve the distinction between title $\mathrm{X}$ programs and abortion as a method of family planning."30 The agency pointed to reports from the Office of the Inspector General and the General Accounting Office (GAO) that recommended that HHS clarify its section 1008 regulations. The GAO's audit of some clinics disclosed "questionable" practices that included failing to present alternatives to abortion to pregnant clients, and providing brochures "promoting abortion as a back-up method of family planning." 31 HHS also relied upon the testimony of women who underwent abortions after receiving counseling at title $X$ projects, but later regretted their decisions. ${ }^{32}$ In light of these findings, HHS concluded that the regulations were needed "to set specific standards for compliance with the statutory requirement that none of the funds appropriated under Title $X$ may be used in programs where abortion is a method of family planning."33

The new regulations' expansive interpretation of the phrase " $[t]$ itle $X$ project funds" allows HHS to regulate activities beyond those actually funded by title $\mathrm{X}$. The characterization of a title $\mathrm{X}$ project as a project, clinic, or program receiving title $X$ funds is unchanged, but "project funds" now include all funds that flow into the project, not solely federal funds. ${ }^{34}$ Thus, all of a clinic's funds, whatever their source, are brought within the regulations. A clinic's expenditure of some of its nonfederal fee mcome on forbidden activities would be an impermissible use of title $X$ funds under the new definition and would subject the clinic to the loss of its title $X$ grants.

Since HHS now defines "family planning" as services, information, and instruction that occur before conception, the title $X$ projects cannot provide any family planning services to pregnant women. "Family planning does not include pregnancy care" or abortion, ${ }^{35}$ and pregnant clients cannot obtain services at family planning clinics. ${ }^{36}$

These new definitions of key terms in the regulations lay the ground-

H.R. CONF. ReP. No. 1667, 91st Cong., 2d Sess. 8 (1970), reprinted in 1970 U.S. CODE CoNG. \& ADM1N. NEWS 5081-82.

30. .53 Fed. Reg. 2923 (1988).

31. Id. at 2924 (quoting Comp. Gen. Rep. No. GAO/HRD-82-106 (1982)).

32. Id. The following is a typical comment quoted in the Agency's statement: "I was not given a complete picture of my situation. Therefore the decision I made for abortion was no decision at all. It was a coercion. Sixteen ycar old girls do not have the where-with-all to make such a life threatening, life changing decision especially when the choices given are so deceitfully incomplete. If I had known the reality of what I chose, I would not have chosen an abortion. I killed my baby!" Id. (emphasis in original).

33. Id. at 2922 (1988).

34. "Title $X$ project funds include all funds allocated to the Title $X$ program, including but not limited to grant funds, grant-related income or matching funds." 42 C.F.R. $§ 59.2$ (1988).

35. Id.

36. See the example $i d . \S 59.8(b)(1)$ (explaining that a pregnant client of a title $\mathrm{X}$ project who 
work for the crucial provision of the regulations-the absolute ban on abortion counseling and referral by title $\mathrm{X}$ clinics. ${ }^{37}$ Thus clinics must refer their pregnant chents to other health care providers ${ }^{38}$ but not to providers that offer abortion information, counsehing, or procedures. The only allowable referrals are to "available providers that promote the welfare of mother and unborn child." 39

The regulations also forbid "indirect" encouragement of abortion. "Indirect" encouragement includes weighing a referral list in favor of abortion providers, listing health care providers whose primcipal business is to provide abortions, excluding from the list available providers who do not provide abortions, "steering" clients to providers who offer abortion as a method of family planning, providing brochures that advertise abortion chimcs, and making abortion climic appointments for pregnant clients. $^{40}$

The regulations target the projects' political activities as well. Title $\mathrm{X}$ projects inay not "encourage, promote or advocate abortion as a method of family planning," nor can they act to increase the availability of abortion. ${ }^{41}$ Forbidden activities include lobbying for legislation to increase the accessibility of abortion, paying dues to groups that advocate abortion, suing to inake abortion more available, and publishing or distributing materials advocating abortion as a method of family planning. ${ }^{42}$ For example, a title $X$ project cannot pay dues to a state association that lobbies "for the passage of legislation to protect and expand the legal availability of abortion as a method of family planming." 43

The "maintenance of program integrity" section of the new regulations requires that the title $X$ project be "physically and financially separate ... from prohibited activities," such as abortion counseling, referral, and lobbying. ${ }^{44}$ Relevant but not dispositive factors in the Secretary's case-by-case determination of whether a clinic meets the separation requirement include separate bookkeeping, separate personnel, and sepa-

requests prenatal care from the project must be referred elsewhere, even though the project personnel are fully qualified to render the care she seeks).

37. Title $\mathrm{X}$ projects "may not provide counseling concerning the use of abortion as a method of family planning or provide referral for abortion as a method of family planning." Id. $§ 59.8(a)(1)$.

38. "Because Title $X$ funds are intended only for family planning, once a client served by a Title $\mathrm{X}$ project is diagnosed as pregnant, she must be referred for appropriate prenatal" care. Id. $\S 59.8(\mathrm{a})(2)$.

39. Id.

40. 42 C.F.R. $\$ \S 59.8(a)(3), 59.10(\mathrm{~b})(1)-(2)(1988)$.

41. Id. $\S 59.10(\mathrm{a})$.

42. Id. $\S 59.10(\mathrm{a})(1)-(5)$.

43. Id. $\S 59.10(\mathrm{~b})(3)$. A separate affiliate, however, using "non-project funds," may pay dues to lobbying organizations. Title X project employees can lobby on their own time and at their own expense. Id. $\$ 59.10(\mathrm{~b})(4)-(7)$.

44. 42 C.F.R. $\$ 59.9$ (1988). 
rate physical facilities. ${ }^{45}$ The separation requirement thus imposes an enormous financial burden on clinics that wish to continue their prochoice activities.

Various plaintiffs challenged the regulations in the spring of 1988, before HHS began implementing them. Of the three district courts that considered the validity of the regulations, two struck them down on constitutional and administrative law grounds, ${ }^{46}$ and one upheld them. ${ }^{47}$ The First Circuit, on appeal, held that the regulations violate both the constitutional right to reproductive autonomy and the first amendment, but withdrew its opinion after the Supreme Court handed down Webster. ${ }^{48}$ Webster threw into doubt the First Circuit's conclusion that the regulations violate "the right of reproductive choice," 49 but did not touch the First Circuit's finding that the HHS grants were an "attempt[] to limit public discussion on abortion rights [and] a violation of the first amendment."so

II

\section{BACKGROUND LAW}

\section{A. Unconstitutional Conditions}

The first amendment checks the government's power to take actions that directly infringe on free speech, but it is silent about government's power "to place conditions upon expenditures as a means of regulating conduct that would otherwise be beyond its control."51 The unconstitutional conditions doctrine analyzes the constitutionality of government actions that condition receipt of a government benefit on the recipient's abstention from constitutionally protected behavior.

The doctrine is implicated when the government refuses to subsidize certain activities it could not constitutionally prohibit. It rests on the notion that government should not be able to do indirectly what it can-

45. Id. § 59.9(a)-(d).

46. Planned Parenthood Fed'n of America v. Bowen, 680 F. Supp. 1465 (D. Colo. 1988); Massachusetts v. Bowen, 679 F. Supp. 137 (D. Mass. 1988), aff'd sub nom. Massachusetts v. Secretary of Health and Human Servs., 873 F.2d 1528 (1st Cir. 1989).

47. New York v. Bowen, 690 F. Supp. 1261 (S.D.N.Y.) (no abuse of administrative discretion and no constitutional violation in the decision to subsidize only some types of speech), aff'd without opinion, 863 F.2d 46 (2d Cir. 1988), cert. denied sub nom. Williams v. New York, 109 S. Ct. 3255, aff'd on rehearing sub nom. New York v. Sullivan, 889 F.2d 401 (2d Cir. 1989).

48. Massachusetts v. Secretary of Health and Human Servs., 873 F.2d 1528 (1st Cir. 1989), vacated, No. 88-1279 (Aug. 9, 1989) reheard en banc, No. 88-1279 (1st Cir. Dec. 5, 1989).

49. Id. at 1539 .

50. Id. at 1546.

51. Rosenthal, Conditional Federal Spending and the Constitution, 39 STAN. L. REv. 1103, 1105,1109 (1987). If Congress' power to attach conditions were truly unlimited, then Congress would have a powerful new tool with which to reshape civil liberties and the federal-state balance. Id. at 1105-06. 
not do directly. As one author explained, "even if [government] has absolute discretion to grant or deny a privilege or a benefit, it cannot grant the privilege subject to conditions that improperly 'coerce,' 'pressure,' or 'induce' the waiver of constitutional rights."52 Thus, although Congress could eliminate title $\mathrm{X}$ grants altogether, it is arguably inproper for HHS to force title $\mathrm{X}$ grantees to choose between receiving the grants and refraining from protected speech, or refusing the grants and exercising their speech rights. ${ }^{53}$

Arguinents about whether a given condition in a government grant is "unconstitutional" currently focus on the distinction between subsidies and penalties. ${ }^{54}$ This approach represents a shift froin the earlier notion that benefits, as a "privilege" extended by the grace of government, could be withheld for any reason-the right privilege doctrine. ${ }^{55}$ Given the pervasive role of federal funding in modern American life, continued application of the right-privilege doctrine would now offer the federal government extensive power to induce and coerce the waiver of constitutional rights. States, localities, and the private sector mcreasingly depend

52. Epstein, The Supreme Court, 1987 Term-Foreword: Unconstitutional Conditions, State Power, and the Limits of Consent, 102 HARV. L. REv. 5, 6-7 (1988). The unconstitutional conditions doctrine has spawned academic literature dating back to the 1920 s. Three recent articles that discuss the field extensively provided many of the ideas and sources used in this comment. See Epstein, supra; Kreimer, Allocational Sanctions: The Problem of Negative Rights in a Positive State, 132 U. PA. L. REV. 1293 (1984); Rosenthal, supra note 51; see also O'Neil, Unconstitutional Conditions: Welfare Benefits with Strings Attached, 54 Calif. L. REv. 443 (1966); Van Alstyne, The Demise of the Right-Privilege Distinction in Constitutional Law, 81 HARV. L. REv. 1439 (1968); Willcox, Invasions of the First Amendment Through Conditioned Public Spending, 41 CoRNELL L.Q. 12 (1955).

53. See infra notes $140-75$ and accompanying text for a discussion of how the regulations violate the first amendment rights of climics by imposing an unconstitutional condition on receipt of the title $\mathrm{X}$ benefits.

The conclusion that title $\mathrm{X}$ regulations violate the rule against unconstitutional conditions is also reached in Note, The Title $X$ Family Planning Gag Rule: Can the Government Buy Up Constitutional Rights?, 41 STAN L. REV. 401 (1989) (authored by Carole I. Chervin).

54. See, e.g., Massachusetts v. Bowen, 679 F. Supp. 137, 145 (D. Mass. 1988), aff'd sub nom. Massachusetts v. Secretary of Healtlı and Human Servs., 873 F.2d 1528 (1st Cir. 1989) (invalidating the HHS regulations). But see New York v. Bowen, 690 F. Supp. 1261, 1273-74 (S.D.N.Y.) (upholding the regulations), aff'd without opinion, 863 F.2d 46 (2d Cir. 1988), cert. denied sub nom. Williams v. New York, 109 S. Ct. 3255, aff'd on rehearing sub nom. New York v. Sullivan, 889 F.2d 401 (2d Cir. 1989).

55. The carliest and purest statement of the right-privilege doctrine came from Justice Holmes, who stated, in the course of upholding the firing of a policcman who had violated a work rule restricting his political activities:

The petitioner may have a constitutional right to talk politics, but he has no constitutional right to be a policeman. There are few employments for hire in which the servant does not agree to suspend his constitutional rights of free speech, as well as of idleness by the implied terms of his contract. The servant cannot complain, as he takes the employment on the terms which are offered him.

McAuliffe v. Mayor of New Bedford, 155 Mass. 216, 220, 29 N.E. 517, $517-18$ (1892). 
on federal grants and federal contracts, ${ }^{56}$ and "opportunities abound for governmental intrusion through allocation of benefits." 57 If the government were free to condition all of its grants on the recipient's waiver of her constitutional rights, those rights would quickly lose their value. ${ }^{58}$

The Supreme Court has replaced the right-privilege analysis with a distinction between a refusal to subsidize the exercise of a right and a penalty on the exercise of that right. ${ }^{59}$ While the Constitution "does not confer an entitlement to such funds as may be necessary to realize all the advantages of" " one's constitutional freedoms, ${ }^{60}$ the government

56. The government employs about $20 \%$ of the workforce, and its expenditures amount to onethird of the gross national product. Kreimer, supra note 52, at 1296.

57. Id. Using threats of withholding a federal benefit to coerce compliance with a federal policy is commonplace, and its propriety is seldom questioned. For current examples, sec Hirn, Drug Tests Threaten Employers, Too, N.Y. Times, Nov. 12, 1988, at 15 ("Under proposed [federal drug testing] rules, the Urban Mass Transportation Agency will deny Federal funding, which amounts to $\$ 3$ billion a year, to mass transit systems that do not implement random testing."). The tactic has an irresistible lure for Republicans and Democrats alike. Consider, for example, the proposals of Frank Mankiewicz, a nationally prominent Democrat, for improving the quality of the presidential election campaign: "Condition federal election money to candidates on a series of unscripted, face-to-face debates. Condition television licenses on agreement by the networks to give a certain amount of free time to the candidates." N.Y. Times, Nov. 13, 1988, $\S 4$, at 1.

The recent controversy over federal funding for the National Endowment for the Arts shows that some politicians consider it entirely proper for Congress to take a direct role in assessing the artistic merit of federally subsidized art. See Senate Votes to Bar U.S. Support of 'Obscene or Indecent' Artwork, N.Y. Times, July 27, 1989, at A1, col. 5; Art on the Firing Line, N.Y. Times, July $9,1989, \S 2$, at 1 .

Recent challenges to conditional federal spending include South Dakota v. Dole, 438 U.S. 203 (1987) (upholding the conditioning of federal highway funds on states' willingness to raise their drinking age to 21); Bowen v. American Hosp. Ass'n., 476 U.S. 610 (1986) (striking down “Baby Doe" regulations that withheld grants from hospitals that did not aggressively treat deformed infants); Selective Serv. Sys. v. Minnesota Pub. Interest Research Group, 468 U.S. 841 (1984) (upholding denial of government student loans to students who did not register for the draft).

58. As early as 1926, Justice Sutherland recognized the dangers of unfettered government discretion in granting and withholding benefits. "If the state may compel the surrender of one constitutional right as a condition of its favor, it may, in like manner, compel a surrender of all. It is inconceivable that guarantees embedded in the Constitution of the United States may thus bc manipulated out of existence." Frost \& Frost Trucking Co. v. Railroad Comm'n, 271 U.S. 583, 594 (1926) (state could not deny private trucking company access to the public highways where eompany refused to obtain a permit certifying that it was willing to act as a common carrier); see also Branti v. Finkel, 445 U.S. 507, 515 (1980) (public employees protected from discharge because of their political party affiliation); Keyishian v. Board of Regents, 385 U.S. 589, 605 (1967) (teaching position in public university cannot "be conditioned upon the surrender of constitutional rights which could not be abridged by direct government action").

59. Persons ordinarily have "no 'right' to a valuable governmental benefit." Perry v. Sindermann, 408 U.S. 593, 597 (1972). Note, however, that in Perry, the Court held that an untenured professor made out a "bona fide constitutional claim" when he alleged that his one-year contract was not renewed because he had made public statements critical of the college's administration. Id. at 598.

60. Lyng v. International Union, UAW, 108 S. Ct. 1184, 1191 (1988) (quoting Regan v. Taxation with Representation, 461 U.S. 540, 550 (1983)) (whether there should be federal subsidization of constitutionally protected choice is a matter for Congress, not a matter of constitutional entitlement); see also Harris v. McRae, 448 U.S. 297, 318 (1980). 
does not have complete freedom in deciding whether to grant or withhold the benefit. ${ }^{61}$ In withholding a benefit, "there are some reasons upon which the government may not rely. It may not deny a benefit to a person on a basis that infringes his constitutionally protected interests; especially, his interest in freedom of speech." 62 If a benefit could be denied because a speaker engaged in "constitutionally protected speech... his exercise of those freedoms would in effect be penalized and inhibited." 63 It is no longer an accepted notion that the receipt of a government benefit is a privilege to which the state may attach any conditions. ${ }^{64}$ It is, quite simply, unconstitutional to make someone "choose between the exercise of a First Amendment right and participation in an otherwise available public program."65

Cases striking down the granting of conditional benefits illustrate how courts have applied this penalty analysis. For example, a state cannot deny a tax exemption to speakers who engage in certain forms of expression, because to deny the exemption is "in effect to penalize them for sucl speecl." 66 Similarly, a state cannot deny unemployment benefits to claimants who are fired because their religious beliefs prevent them from working on Saturdays. ${ }^{67}$ Furthermore, a state cannot impose a oneyear waiting requirement for welfare benefits on families that move in from outside the state because the rule violates equal protection by "invidious[ly] discriminat[ing]" against those who exercise their "fundamental riglit of interstate inovement." 68

\section{Government Encouragement of Its Preferred Choice}

The penalty analysis is not, however, as clear cut as these cases inay

61. Perry, 408 U.S. at 597

62. Perry, 408 U.S. at 597; see also Frazee v. Illinois Dep't of Emp. Sec., 109 S. Ct. 1514 (1989); Frost, 271 U.S. at 594 (government "may not impose conditions which require the relinquishment of constitutional rights").

63. Perry, 408 U.S. at 597.

64. See, e.g., Sherbert v. Verner, 374 U.S. $398,404 \&$ n.6 (1963) (rejecting the right-privilege distinction and citing numerous examples from the state courts where conditions on the receipt of government benefits have been struck down "because of their tendency to inhibit constitutionally protected activity"). But see United States Civil Serv. Comm'n v. National Ass'n of Letter Carriers, 413 U.S. 548 (1973) (upholding, over first amendment objections, Hatch Act provisions that bar many civil servants from involvement in party politics).

65. Thomas v. Review Bd., 450 U.S. 707, 708 (1981) (unemployment benefits awarded to Jehovah's witness who resigned from arms factory).

66. Speiser v. Randal1, 357 U.S. 513, 518 (1958) (striking down state property tax exemption that was conditioned on loyalty oath).

67. Sherbert v. Verner, 374 U.S. 398 (1963) (state's attempt to condition receipt of unemployment benefits on plaintiff's willingness to work on Saturdays unconstitutionally inhibited the exercise of her first amendment freedoms). For later applications of Sherbert in similar factual settings, see Hobbie v. Unemployment Appeals Comm'n, 480 U.S. 136 (1987); Frazee v. 111. Dep't of Employment Sec., 109 S. Ct. 1514 (1989).

68. Shapiro v. Thompson, 394 U.S. $618,627-38$ (1969). 
indicate. Since much government spending is legitimately designed to encourage one type of behavior or activity, it is often unclear whether the nonfunded behavior or activity is penalized or simply not subsidized.

Specifically, in three major abortion funding cases, the Supreme Court permitted the government to favor childbirth and discourage abortion through its funding choices. In Maher v. Roe, ${ }^{69} \mathrm{Harris}$ v. McRae, ${ }^{70}$ and Webster v. Reproductive Health Services, ${ }^{71}$ the Court found that government has authority to make this choice ${ }^{72}$ because childbirth is deemed to be in the public interest. ${ }^{73}$

In Maher, the Court held that a state could refuse to pay for nontherapeutic abortions for indigent women, even though its Medicaid program reimbursed women for expenses associated with childbirth. The decision proceeded from the preimse that the state is not obligated to pay any medical expenses of mdigents. ${ }^{74}$ The Court declared that if the state's regnlatory scheme "impinge[d] upon a fundamental right explicitly or implicitly protected by the Constitution," then it would receive strict judicial scrutiny and presumably be struck down. ${ }^{75}$ But the Court

69. 432 U.S. 464 (1977). In Beal v. Doe, 432 U.S. 438 (1977), a companion case decided the same day, the Court held that states did not have to fund nontherapeutic abortions in order to participate in the joint federal-state Medicaid program.

70. 448 U.S. 297 (1980).

71. 109 S. Ct. 3040 (1989).

72. Maher, 432 U.S. at 474.

73. Harris, 448 U.S. at 315.

74. Maher, 432 U.S. at 469 . The assumption is that the greater power to deny a benefit altogether includes the lesser power to bestow that benefit. $C f$. Western Union Tel. Co. v. Kansas, 216 U.S. 1, 53 (1910) (Holmes, J., dissenting) ("Even in the law, the whole generally includes its parts. If the State may prohibit, it may prohibit with the privilege of avoiding the prohibition in a certain way."). See Epstein, supra note 52, at 90 (to deny Medicaid altogether is the greater power, to exclude certain medical procedures from Medicaid coverage is the lesser power).

75. 432 U.S. at 470 (quoting San Antonio School Bd. v. Rodriguez, 411 U.S. 1, 17 (1973). See generally Gunther, The Supreme Court, 1971 Term - Foreword: In Search of Evolving Doctrine on a Changing Court: A Model for a Newer Equal Protection, 86 HARv. L. REv. 1, 8 (1972) (calling such strict scrutiny " "strict' in theory and fatal in fact").

The Maher court easily concluded that the refusal to fund abortions does not operate to disadvantage any suspect class. Unlike, for example, racial minorities, the poor are not a "suspect" constitutional class. 432 U.S. at 470-71; see also Kadrmas v. Dickinson Pub. Schools, 108 S. Ct. 2481,2487 (1988) (statutes having different effects upon rich and poor are not necessarily subject to strict equal protection scrutiny). For an elaborate defense of this position, see Michelman, Foreword: On Protecting the Poor Through the Fourteenth Amendment, 83 HaRv. L. REv. 7 (1969), in which the author argues that "the risk of exposure to markets and their 'decisions' is not normally deemed objectionable, to say the least, in our society." Id. at 27-28.

Justice Powell easily distinguished a line of cases holding that the government was required to fund indigents in the exercise of some constitutional rights. 432 U.S. at 471 n.6. Where the state holds a monopoly on a right-for example, to vote, to grant a divorce, or to bring a criminal appeal-then the state cannot condition the exercise of the right on the ability to pay. See, e.g., Boddie v. Connecticut, 401 U.S. 371 (1971) (divorce filing fee invalid); Harper v. Virginia Bd. of Elections, 383 U.S. 663 (1966) (poll tax invalid); Douglas v. California, 372 U.S. 353 (1963) (indigent's right to counsel in criminal appeals); Griffin v. Illinois, 351 U.S. 12 (1956) (indigents' right to trial transcripts in criminal appeals). Since the women who challenged the Medicaid 
found no violation of the rights established in Roe v. Wade:

[The right guaranteed in Roe] implies no limitation on the authority of a State to inake a value judgment favoring childbirth over abortion, and to implement that judgment by the allocation of public funds ....

There is a basic difference between direct state interference with a protected activity and state encouragement of an alternative activity consonant with legislative policy. ${ }^{76}$

As an example, the Court noted that the "liberty" recognized in the fourteenth amendment grants parents the right to send their children to private school, but does not require the state to pay for private education, or prevent the state from funding public education, its preferred alternative. ${ }^{77}$

In Harris v. $\mathrm{McRae}^{78}$, decided three years after Maher, the Court considered whether Congress can refuse to subsidize medically necessary abortions for indigent women. The Court held that while Congress cannot place additional obstacles in the path of women seeking abortions, it is not obhigated to reinove obstacles such as poverty that women already face. Since Congress could have cliosen not to subsidize health care at all, its decision to fund only some procedures did not leave a woman any worse off than she otherwise would have been. The Harris opimion highlights Congress' encourageinent of childbirth over abortion through its allocation of public funds. ${ }^{79}$

In the Court's most recent abortion case, Webster v. Reproductive Health Services, ${ }^{80}$ a divided Court upheld Missouri's prohibition on the use of public facilities or einployees to perform abortions. The Court found "[n]othing in the Constitution requiring States to enter or remain in the busmess of performing abortions." ${ }^{\prime 11}$ If the state could prohibit public funding of abortion, the majority reasoned, the patient would incur no additional burden by having to go to a private provider of abortions. $^{82}$

\section{The Separate Affiliate Doctrine}

One measure of whether a demial of funding is a "penalty" is the degree to which it prevents the recipient from using outside funds to perform the nonfunded activity. Under the "separate affiliate" doctrine, a

Iestriction in Maher theoretically could obtain abortions from private physicians, Justice Powell concluded that the government monopoly cases were inapposite.

76. 432 U.S. at $474-75$ (footnote omitted).

77. Id. at 476-77 (discussing Meyer v. Nebraska, 262 U.S. 390 (1923) and its progeny).

78. 448 U.S. 297 (1980).

79. Id. at 315-19.

80. 109 S. Ct. 3040 (1989).

81. Id. at 3052 (even if the public hospital recouped the entire cost of performing the abortion from the patient, the prohibition would still be constitutional).

82. Id. 
subsidized entity may continue to receive federal funding by creating a separate affiliate that uses private funds to support the federally disfavored activity. The government may not withhold funds from the recipient for engaging in the proscribed activity, provided the recipient does so through its separate affiliate. The Court sketched the contours of the separate affiliate doctrine in Regan $v$. Taxation with Representation ${ }^{83}$ and FCC $v$. League of Women Voters. ${ }^{84}$

In Regan, a nonprofit tax lobbying group challenged Internal Revenue Code sections that distinguish between two types of nonprofit, taxexempt organizations. Contributions to nonprofit organizations that do not lobby are tax deductible; contributions to such organizations that do lobby are not deductible. Plaintiff, a group that sought to use its tax deductible contributions for its lobbying activities, challenged the statute on first amendment grounds. The Court upheld the statute, finding a rationally based Congressional choice "not to subsidize lobbying as extensively as it chose to subsidize other activities that nonprofit organizations undertake to promote the public welfare."85 Government has no obligation to fund every attempt to exercise a fundamental right. ${ }^{86}$

The Court stressed that the challenged Code sections did not bar the group from lobbying altogether; they merely prevented the group from using tax deductible donations in its lobbying efforts. The Court noted that the plaintiff had the option of establishing a dual corporate structure. One entity could engage in nonlobbying activities, such as publishmg a journal, which would be funded with tax deductible contributions; the second entity could lobby if it did not use tax deductible funds to do so. Provided the two groups took the not "unduly burdensome" steps of incorporating separately and maintaining separate financial records, the Code rules would be satisfied. ${ }^{87}$

One year after Regan, the Court suggested that the separate affiliate doctrine applied where Congress sought to condition a grant on the recipient's refraining from certain "pure" speech. The Court in FCC v. League of Women Voters ${ }^{88}$ held unconstitutional a statute that barred editorializing by federally supported public television stations. Signifi-

83. 461 U.S. 540 (1983).

84. 468 U.S. 364 (1984).

85. 461 U.S. at 544.

86. See id. at 545 . The Court also stated, "We have held in several contexts that a legislature's decision not to subsidize the exercise of a fundamental right does not infringe the right, and thus is not subject to strict scrutiny." Id. at 549 (citing Buckley v. Valeo, 424 U.S. 1 (1976)). Although veterans' groups are exempt from the lobbying restriction, their special status did not violate equal protection because the classification was rationally related to the legitimate government objective of rewarding veterans for their past sacrifices. See id. at 547 (stating equal protection test), 550-51 (discussing congressional policy of rewarding veterans).

87. Id. at $544 \&$ n. 6 .

88. 468 U.S. 364 (1984). 
cantly, the Court noted that a different result would have obtained had Congress provided for the creation of separate, nonfunded affiliates for the purpose of editorializing. ${ }^{89}$

\section{B. First Amendment's Requirements of Content and Viewpoint Neutrality}

An issue of unconstitutional conditions arises where government conditions the payment of a benefit on the recipient's failure to assert an independent constitutional right. In the case of the HHS regulations, the underlying right at issue is free speech.

Since $1938,{ }^{90}$ the Court has recognized a hierarchy of constitutional values $^{91}$ and has closely scrutinized legislation that inpinges on fundamental rights. ${ }^{92}$ First amendinent freedoms traditionally occupy a "preferred position" at the very top of the hierarchy. ${ }^{93}$ Free speech rights are among the "islands of 'preferred freedonis" " protected from governmental intrusion unless government can muster a coinpelling justification for the interference. ${ }^{94}$ This doctrine protects speech from executive and judicial restrictions as well as from congressional actions. ${ }^{95}$

The extensive protection of speech steins from the value of the coinpetition of ideas in the niarketplace, the role speech plays in the political process, and the individual self-realization that derives from free expression. ${ }^{96}$ Any law inaking conımunication more difficult raises a first aniendinent question; any reduction in the total quantity of available expression requires a high level of governmental justification. ${ }^{97}$ The first ainendınent prevents governnent "from limiting the stock of information

89. Id. at 400-01.

90. United States v. Carolene Prods. Co., 304 U.S. 144, 152 n.4 (1938).

91. Legislation involving access to ordinary social and economic advantage is presumed constitutional if it has a rational basis. But "legislation which restricts those political processes which can ordinarily be expected to bring about repeal of undesirable legislation[] is ... subjected to more exacting judicial scrutiny" because it distorts the political process itself. Id. Legislation subject to stricter scrutiny includes "restraints upon the dissemination of information . . . [and] interferences with political organizations." Id. (citations omitted).

92. Epstein, supra note 52, at 55.

93. Murdock v. Pennsylvania, 319 U.S. 105, 115 (1943) ("Freedom of press, freedom of speech, freedom of religion are in a preferred position.").

94. L. Tribe, American Constitutional Law 8 (2d ed. 1988).

95. "Congress shall make no law ... abridging the freedom of speech, or of the press . . . " U.S. ConsT. amend. I; see, e.g., Cornelius v. NAACP Legal Defense \& Educ. Fund, 473 U.S. 788 (1985) (challenge to executive regulation); Nebraska Press Ass'n v. Stuart, 427 U.S. 539 (1976) (challenge to trial court's gag order). But cf. Denbeaux, The First Word of the First Amendment, 80 Nw. U.L. REV. 1156 (1986) (arguing that the first amendment prevents only congressional actions infringing on free speech).

96. See J. NowaK, R. Rotunda \& J. Young, Constrtutional LAw 835-36 (3d ed. 1986); Stone, Content Regulation and the First Amendment, 25 WM. \& MARY L. REV. 189, 193 (1983).

97. See Buckley v. Valeo, 424 U.S. 1, 19 (1976) (in striking down certain limits on campaign financing, the Court observed that a spending limit "necessarily reduces the quantity of expression 
from which members of the public may draw."98

These principles have led the Court to view skeptically governmental attempts to limit speech based on its subject or content. "[T]he First Amendment means that government has no power to restrict expression because of its message, its ideas, its subject matter, or its con-

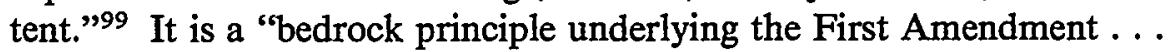
that the Government may not prohibit the expression of an idea simply because society finds the idea itself offensive or disagreeable."100 The Court has struck down virtually every content-based restriction it has considered in the past thirty years. ${ }^{101}$ It subjects content-based regulations to "the most exacting scrutiny,"102 and finds the first amendment "hostil[e] . . . to prohibition of public discussion of an entire topic."103 The Court, however, does not subject content-neutral restrictions on

by restricting the number of issues discussed, the depth of their exploration, and the size of the audience reached") (footnote omitted); see Stone, supra note 96, at 192-93.

98. Richmond Newspapers, Inc. v. Virginia, 448 U.S. 555, 576 (1980) (Burger, C.J., plurality opinion) (upholding public's right of access to criminal trials) (quoting First Nat'l Bank v. Bellotti, 435 U.S. 765, 783 (1978)).

99. Police Dep't. v. Mosely, 408 U.S. 92, 95 (1972) (citations omitted) (invalidating ordinance that forbade all but peaceful labor picketing near elementary schools); see also Boos v. Barry, 485 U.S. 312, 321 (1988) (ban on political protests near foreign embassies violates first amendment); Consolidated Edison Co. v. Public Serv. Comm'n, 447 U.S. 530, $536-37$ (1980) (overturning Commission's ruling that would have barred utilities from inserting messages about controversial issues of public policy into its monthly bills); Virginia State Bd. of Pharmacy v. Virginia Citizens Consumer Council, 425 U.S. 748, 761 (1976) (striking down restrictions on the advertising of prescription drugs because the statute "single[d] out speech of a particular content and [sought] to prevent its dissemination completely"); Erznoznik v. City of Jacksonville, 422 U.S. 205 (1975) (holding unconstitutional an ordinance that barred nude scenes at drive-in theatres because it discriminated solely on the basis of the content of the movies).

For the content-neutrality doctrine applied to the HHS regulations, see Massachusetts $v$. Bowen, 873 F.2d 1528, 1545-46 (1st Cir. 1989) (holding the regulations' content and viewpoint discriminatory); Planned Parenthood Fed'n of America v. Bowen, 680 F. Supp. 1465, 1477 (D. Colo. 1988) (same). Contra New York v. Bowen, 690 F. Supp. 1273 (S.D.N.Y.) (no first amendment violation), aff'd without opinion, 863 F.2d 46 (2d Cir. 1988), cert. denied sub nom. Williams v. New York, 109 S. Ct. 3255, aff'd on rehearing sub nom. New York v. Sullivan, 889 F.2d 401 (2d Cir. 1989).

See generally Stephan, The First Amendment and Content Discrimination, 68 VA. L. REv. 203 (1982) (arguing that the Court has not followed the sweeping commitment to content neutrality it undertook in Mosely and proposing a hierarchy of protected eategories of expression); Redish, The Content Distinction in First Amendment Analysis, 34 STAN. L. REv. 113 (1981) (calling for an abandonment of the distinction between content-neutral and content-based regulation); Karst, Equality as a Central Principle in the First Amendment, 43 U. CHI. L. Rev. 20, 29-35 (1975) (discussing a theory of equality as a bar to content discrimination).

100. Texas v. Johnson, 109 S. Ct. 2533, 2544 (1989) (citations omitted) (state fiag desecration statute unconstitutional).

101. Stone, supra note 96, at 196. Professor Stone excluded from this generalization obscenity, commercial speech, and other types of speech that traditionally have been afforded less first amendment protection. Id. at 194-95.

102. Widmar v. Vincent, 454 U.S. 263, 276 (1981) (state university cannot exclude student religious groups from using school facilities otherwise open to the student body).

103. Consolidated Edison Co., 447 U.S. at 537. But cf. id. at 538 n.5 (noting that in "narrow 
speech to heightened review. ${ }^{104}$

In contrast to content-based restrictions, which suppress whole categories of speech, ${ }^{105}$ viewpoint-based statutes single out a particular idea for a special penalty while leaving speech about related or coinpeting ideas unrestricted. 106 Viewpoint-based statutes thus seein particularly inconsistent with the values underlying the first amendinent.

Viewpoint-based restrictions distort the public debate and affect "the thinking process of the community" 107 by eliminating one idea froin public discussion. Government atteinpts "substantially to eliminate particular ideas, viewpoints, or iteins of information froin public debate . . . undermine the values and purposes underlying the first ainendinent." 108 Furthermore, government inay not "restrict the speech of soine elements of . . . society in order to enhance the relative voice of others." 109 Accordingly, the Court repeatedly has held viewpoint-based restrictions on speech unconstitutional. For example, the Court has invalidated soine actions by administrative agencies because of the risk that the agency may restrict communication " 'merely because public officials disapprove of the speaker's views'."110

The Court has also held indirect suppression of disfavored viewpoints to be impermissible. In Cornelius v. NAACP Legal Defense \& Education Fund, ${ }^{111}$ the Court upheld the exclusion of advocacy groups

circumstances" the Court may analyze the content of expression to determine if it warrants any first amendment protection at all (citing cases on commercial speech, obscenity, and fighting words)).

104. See, e.g., United States v. O'Brien, 391 U.S. 367, 377 (1968) (upholding anti-war protester's conviction for draft card destrnction in part because the government interest in forbidding destruction was "unrelated to the suppression of free expression").

105. See Stone, Restrictions of Speech Because of its Content: The Peculiar Case of SubjectMatter Restrictions, 46 U. CH1. L. REV. 81,81 (1978).

106. Stephan, supra note 99 , at 218 .

107. Stone, supra note 96, at 198 (quoting A. Melklejohn, Political Freedom 27 (1960)).

108. Id. at 199.

109. Buckley v. Valeo, 424 U.S. 1, $48-49$ (1976).

110. Consolidated Edison Co., 447 U.S. at 536 (quoting Niemotko v. Maryland, 340 U.S. 268, 282 (1951) (Frankfurter, J., concurring in result)); see also First Nat'l Bank v. Bellotti, 435 U.S. 765, $791 \mathrm{n} .31$ (1978) ("[g]overnment is forbidden to assume the task of ultimate judgment [of] the relative merits of conflicting arguments") (citations omitted); Linmark Assocs. v. Township of Willingboro, 431 U.S. 85, 96-97 (1977) (invalidating ordinance that forbade homeowners from posting "for sale" signs in effort to curb white flight because city council's inotivation was to suppress information that conveyed that town was not a desirable place to live); Schacht v. United States, 398 U.S. 58 (1970) (Congress could not forbid wearing of Army military uniforms in a manner "tend[ing] to discredit" the armed forces); Tinker v. Des Moines Indep. Comm. School Dist., 393 U.S. 503, 511 (1969) (school's ban on armbands protesting the Vietnam war was invalid where other political symbols had been allowed: "prohibition of expression of one particular opinion, at lcast without evidence that it is necessary to avoid material and substantial interference with schoolwork or discipline, is not constitutionally permissible"); Cox v. Louisiana, 379 U.S. 559, 580-81 (1965) (Black, J., concurring and dissenting) (statute that prohibited the blocking of traffic but exempted labor union protests was an invalid attempt "to pick and choose annong the views [the State] is willing to have discussed on its streets").

111. 473 U.S. 788 (1985). 
from the combined Federal Campaign Fund charity fund drive, a nonpublic forum. ${ }^{112}$ The Court noted, however, that the result would be different on remand if the NAACP showed that the government sought to "suppress a particular point of view."113 And the Court has warned that "governments might soon seize upon the censorship of particular words as a convenient guise for banning the expression of unpopular views."114

\section{III \\ ANALYSIS \\ A. Flaws in the Unconstitutional Conditions Doctrine}

Under existing doctrine, an evaluation of the HHS regulations asks whether the government's choice to allocate title $X$ funds selectively "penalizes" any protected rights of the clinics. ${ }^{115}$ Consider the exercise of a protected right that is clearly in the grantee's control in the absence of the new regulations: the right to speak on the subject of abortion. A threat to fine clinics one dollar for their abortion-related speecli would unquestionably penalize that speech. The tougher question is whether HHS's threat to witliliold a subsidy to which the clinics are not "entitled" also operates as a penalty.

Defenders of the regulations assert that the government has no obligation to give title $X$ funds to a clinic that supports abortion counseling. ${ }^{116}$ Simce the government is not required to grant any funds or to grant them to any particular program, it can "condition participation in the program upon adlierence to the governmental social policy."117 In this view, no "penalty" is placed on the clinics that lose their benefits; they are simply on the losing end of government's choice to favor childbirth counseling over abortion counseling.

This argument fails to recognize tlie deficiencies of current penalty analysis. Existing doctrine, which focuses on whetlier the regulations "penalize" or merely "refuse to subsidize" the clinics' exercise of a right, ${ }^{18}$ is overly simplistic and ultimately unsatisfactory.

The primary flaw in the "distinction" between penalties and refusals to subsidize is that it is really no distinction at all. A governmental

112. Id.

113. Id. at $811-13$.

114. Cohen v. California, 403 U.S. 15, 26 (1971) (reversing conviction for breach of the peace where defendant wore jacket bearing the slogan "Fuck the Draft" in a courthouse).

115. See supra text accompanying notes 59-68.

116. See Hirt, Why the Government is Not Required to Subsidize Abortion Counseling and Referral, 101 HARV. L. REV. 1895, 1900-01 (1988).

117. Id. at 1909 (footnote omitted).

118. See supra text accompanying notes 59-68. 
action easily can be both, and indeed the Court has implied that the two can be equated in some circumstances. The Court observed in Harris that "[a] refusal to fund a protected activity, without more, cannot be equated with the imposition of a 'penalty' on that activity." 119 The Court's language is curious. A refusal to subsidize does not automatically amount to a penalty, but it can if "something more" is present. The two categories are not inutually exclusive; rather, "penalties" are simply one characterization of some "refusals to subsidize."

A second flaw in the penalty analysis is its overly narrow view of what constitutes a penalty. For example, under the penalty analysis courts consider neither the recipient's rehiance on the conditioned grant nor the condition's effect on the recipient's ability to compete in the marketplace of ideas, even though both factors can affect the grant recipient's cost of engaging in the constitutionally protected behavior. If a grantee has come to rely on federal subsidies for its support over a period of years, the withdrawal of the benefit may move the grantee below the "natural basehine," the "position [that the grantee] would have enjoyed in the normal course of events." 120 In such a case the grantee's dependence on the subsidy may cause it to waive its right to engage in otherwise protected speech. Moreover, conditioning a grant on behavior more conducive to the grantee's competitors than to the grantee puts the grantee at a competitive disadvantage. Grants conditioned on refraining from certain speech, for example, in effect amplify the voices of the speaker's competitors and muffle the voice of the speaker. Where the grantee is forced to sacrifice constitutionally protected behavior in order to receive a grant, the exercise of the constitutional right is penalized. These considerations have not been explicitly recoguized as relevant to the penalty analysis or the unconstitutional conditions doctrine.

The penalty analysis that courts currently use cannot adequately address the constitutional issues that the HHS regulations pose. Its portrayal of conditional spending as a inere refusal to subsidize obscures the fact that the regulations squelch the clinics' speech as effectively as an obviously unconstitutional direct prohibition would. ${ }^{121}$

119. 448 U.S. at 317 n.19 (emphasis added). The Court has since cited Harris for the proposition that the legislature's refusal to subsidize the exercise of a fundamental right does not infringe upon that right. See Regan v. Taxation with Representation, 461 U.S. 540, 549 (1983), citing Harris, Maher, and Buckley v. Valeo, 424 U.S. 1(1976). Harris continues to exert a strong influence on the Court; see, e.g., Lyng v. International Union, UAW, 108 S. Ct. 1184, 1191 (1988) (citing Regan's quotation of Harris) (upholding, over free association and free speech objections, a statute's denial of food stamps to families of strikers who would otherwise become eligible for them because of the strikers' loss of wage income).

120. Kreimer, supra note 52 , at 1353.

121. Even the one court to uphold the regulations recognized that they would be clearly unconstitutional if applied to all health care providers, not just title $\mathrm{X}$ grantees. New York v. Bowen, 690 F. Supp. 1261, 1273 (S.D.N.Y.), aff'd without opinion, 863 F.2d 46 (2d Cir. 1988), cert. 


\section{B. An Alternative Approach}

An alternative to the traditional analysis would focus on the one issue crucial to the constitutionality of any conditional benefit: is the government indirectly suppressing the exercise of a constitutional right that it could not proscribe directly? This approach would entail a three question inquiry into the purpose, effect, and scope of the condition. First, is the goverument's principal reason for imposing the condition constitutionally illegitimate? Second, does the condition in fact obstruct the grantee's ability to exercise an independent constitutional right? Finally, does the condition restrict constitutionally protected behavior beyond what is necessary to achieve the government's stated goal for the condition?

The Supreme Court asked the first two questions in Regan v. Taxation with Representation. ${ }^{122}$ In Regan the Court noted that subsidies " " "aim[ed] at the suppression of dangerous ideas" " "are unconstitutional. ${ }^{123}$ Although the Regan Court upheld a tax exemption to charities that refrained from lobbying, it suggested that the result would have been different had there been some indication that the tax statute "was intended to suppress any ideas" or that it had "had that effect."124 Consequently, both the purpose of an imposed condition and its effect are relevant to its constitutionality.

In reviewing the goverument's intent in establishing a condition that limits constitutionally protected behavior, the government's stated interest should be weighed against the importance of the protected interest. ${ }^{125}$ At times it may be difficult to deterinine the government's motive behind a conditional grant. Legislative and regulatory motives are often mixed, and it is "all but hopeless" to expect courts to isolate a sole impernissible purpose for an action. ${ }^{126}$ Nevertheless, statutory language or legislative history may provide insight into the government's purpose. In cases imvolving limitations on speech, any governmental intent to limit the

denied sub nom. Williams v. New York, $109 \mathrm{~S}$. Ct 3255, aff'd on rehearing sub nom. New York v. Sullivan, 889 F.2d 401 (2d Cir. 1989); see Rosenthal, supra note 51, at 1110 (advocating that a presumption of invalidity should apply to a condition coercing conduct where direct regulation having the same intrusive effect on individual rights would be unconstitutional).

122. 461 U.S. 540 (1983).

123. Id. at 548 (quoting Camarano v. United States, 358 U.S. 498, 513 (1959) (quoting Speiser v. Randall, 357 U.S. 513, 519 (1958))).

124. Id. at 548 .

125. See Rosenthal, supra note 51, at 1121. After reviewing the academic literature and court decisions, Professor Rosenthal finds general acceptance of a balancing approach to resolve the question whether the conferring of a privilege can be conditioned on conduct which government could not otherwise compel.

126. L. TRIBE, supra note 94 , at 823. 
expression to one type of idea or one viewpoint would be illegitimate in $^{127}$ and should weigh heavily against other "legitimate" interests. When such an inquiry is mconclusive, the analysis should then consider the effect of the conditional grant.

Such an "effects" approach was suggested in Regan. There the Court found that the effect of a conditional grant on the expression of ideas would be relevant to the constitutionality of the condition. ${ }^{128}$ An "effects" test would explicitly consider all of the costs of choosing to exercise a constitutional right rather than choosing to enjoy the government benefit. This test would consider the grantee's reliance on past unconditioned subsidies and its ability to contimue operating without the subsidy. It would also consider the competitive disadvantage to which the grantee is subjected by losing the subsidy.

The third and final step in the approach proposed here is an inquiry into the scope of the demal of access to public funding. A number of Supreme Court opinions have indicated that the results of such an analysis are relevant. Harris itself indicates that the validity of a constitutional grant turns on the "[breadth of the] disqualification front receipt of public benefits"; hence, an overly harsh denial of benefits presents "[a] substantial constitutional question." 129 For instance, under Harris, a statute barring a Medicaid recipient who chooses to get an abortion from receiving any Medicaid funds for any treatment would constitute a "penalty" on the exercise of the protected right. ${ }^{130}$ In the same vein, the Court in Sherbert $v$. Verner ${ }^{131}$ determined that a "State may not . . . withhold all unemploynient compensation benefits from a claimant who would otherwise be eligible for such benefits but for the fact that she is unwilling to work ... on her Sabbath."132 Similarly a statute that conditioned the taking of any business expense deductions on businesses' abstaiming from lobbying, would apparently be unconstitutional, even though denial of a deduction for lobbymg expenses is itself constitutional. ${ }^{133}$ Even the plurality in Webster genuflected briefly in recognition of the possibility that sonie cutoffs of access to public benefits "might be" impermissible. The Court, citing Harris, noted that Webster's outcome "might . . . be different if the State barred doctors who performed abortions in private facili-

127. For a survey of the Court's decisions on content and viewpoint based legislation, see supra notes 90-114 and accompanying text.

128. See supra text accompanying note 124 .

129. 448 U.S. at 317 n.19.

130. See id. Tribe similarly points out that food stamp recipients could not be told that they would be cut off and left to starve if they were to use their own money to influence the political process. L. TRIBE, supra note 94 , at 784 n.16.

131. 374 U.S. 398 (1963).

132. Harris, 448 U.S. at 317 n.19, (discussing Sherbert v. Verner, 374 U.S. 398 (1963)) (emphasis in original).

133. See Cammarano v. United States, 358 U.S. 498, 515 (1959) (Douglas, J., concurring). 
ties from the use of public facilities for any purpose."134

Of course, acceptance of the assertion that government may not dispense its benefits in ways which selectively coerce the waiver of first amendment rights still leaves Congress the option of eliminating reproductive health grants altogether. And as a practical political matter, however, this eventuality is unlikely. As a theoretical matter, requiring that all similarly situated health care providers receive a benefit, if any do, respects constitutional principles far more than doctrines allowing the invidious exclusion of disfavored speakers. ${ }^{135}$

Courts asked to sort out a mix of permissible and impermissible motives in other areas of law have sometimes shifted the burden of proof from the plaintiff to the defendant. ${ }^{136}$ Burden shifting and adopting rebuttable presumptions are possible approaches in the analysis of conditional grants as well. ${ }^{137}$ When a clinic challenges the denial of benefits, the government should have to prove that it had a constitutionally legitimate purpose, that the condition did not in effect penalize the clinic for exercising its first amendment rights, and that the scope of the condition was narrowly tailored to the government's stated purpose. Since a conditional grant may have the same effect as a direct criminal sanction against a protected right, ${ }^{138}$ government should have the burden of showing why the grant is permissible where a criminal sanction would not be. ${ }^{139}$

\section{Failure of the HHS Regulations Under the New Approach}

HHS's argument that it is merely refusing to subsidize certain speech overlooks several problems. First, the government's illegitimate purpose of skewing the public debate-about abortion overshadows its

134. 109 S. Ct. 3040,3052 n.8 (1989).

135. See Epstein, supra note 52, at 28. Professor Epstein maintains that when a conditional grant is held unconstitutional, an "empirical question arises whether government will deny [the grantees] a useful benefit altogether, or grant them the benefit without the obnoxious condition." Id.

136. See Texas Dept. of Community Affairs v. Burdine, 450 U.S. 248, 252-56 (1981) (employment discrimination); McDonnell-Douglas Corp. v. Green, 411 U.S. 792, 802 (1973) (same); L. TRIBE, supra note 94, at 821-25 (discussing the relevance of legislative motives); Stone, supra notc 96, at 230 (referring to content regulations, arguing that "if an improper motivation played a substantial role in the government's decision to restrict expression, the restriction must be invalidated") (footnote omitted).

137. See, e.g., Rosenthal, supra note 51 , at 1152 (proposing a presumption that conditions on spending may not be used to coerce otherwise protected conduct; government would have burden of showing why the condition should be treated differently from a regulation).

138. Cf. Kreimer, supra note 52, at 1352 (arguing that infringements on constitutional rights by allocational sanctions or direct criminal sanctions should undergo the same evaluation for constitutionality).

139. Rosenthal, supra note 51, at 1152. Cf. Frazee v. Illinois Dep't of Employment Sec., $109 \mathrm{~S}$. Ct. 1514, 1518 (1989) (burden on state to justify the impingement on religious freedom that resulted from denial of unemployment benefits). 
legitimate purpose of encouraging childbirth. Second, the regulations do penalize clinics for exercising their right to speak by withholding funds upon which the chinics have come to rely and by putting them at a competitive disadvantage relative to subsidized anti-choice clinics. Third, the regulations contam overly broad restrictions on speech in that they prohibit title $\mathrm{X}$ clinics from usmg their own funds to engage in protected speech.

\section{Content and Viewpoint Restrictions: An Impermissible Government Motive}

HHS contends that the regulations are simply an outgrowth of the government's legitimate interest in promoting clildbirth, and that therefore they do not violate the first amendment. It claims that Congress' decision to favor childbirth over abortion and to "implement that choice through the allocation of public funds" is within the scope of its broad authority to condition grants of public funds. ${ }^{140}$ Even though speech in the form of counseling is involved in title $\mathrm{X}$, the argument runs that Congress can nevertheless choose to favor childbirth-promoting speech over abortion-related speech. ${ }^{141}$ The first amendment does not prevent government "from using its resources or media to advocate its own views, even on controversial issues." 142 Therefore, HHS concludes, government promotion of one viewpomt does not unconstitutionally suppress opposing viewpoints.

HHS incorrectly asserts that the regulations rest on a constitution-

140. 53 Fed. Reg. 2935 (1988) (citing Buckley v. Valeo, 424 U.S. 1, 90-91 (1976), Harris v. McRae, 448 U.S. 297, 317 (1980), and Maher v. Roe, 432 U.S. 464 (1977)).

141. Id.

142. Hirt, supra note 116 , at 1905 . While this statement may be-true, the notion that government is just another player in the marketplace of ideas is troublesome. There is a constitutional difference between the executive branch asserting in White House speeches and court briefs that abortion is wrong, and advocating that same position in a multi-million dollar advertising campaign urging viewers to protest in front of abortion chinics. The difference is not merely one of degree. The use of customary political and judicial processes would be constitutional, but the hypothetical advertising campaign, which seeks to inculcate the preferred view in the general public, would not be. The conditional title $\mathrm{X}$ grants do not further government's legitimate goal of directly airing its opinions. Instead, the grants coerce private parties into toeing the government line. The grants seek to transform the clinics into mouthpieces for a government view they may not wish to espouse.

But cf. the position of (then) Judge Scalia in Block v. Meese, 793 F.2d 1303, 1313 (D.C. Cir. 1986), cert. denied, 478 U.S. 1021 (1986) (upholding the labeling of certain foreign films as propaganda) (quoting Lamont v. Postmaster General, 381 U.S. 301, 307 (1965) (quoting New York Times v. Sullivan, 376 U.S. 254, 270 (1964))), where he observed, "Nor does any ease suggest that 'uninhibited, robust, and wide-open debate' consists of debate from which the government is excluded, or an 'uninhibited marketplace of ideas' one in which the government's wares cannot be advertised."

"Government speech" has spawned a considerable literature. See generally M. YUDOF, WHEN Government SpEaks (1983); Shiffrin, Government Speech, 27 UCLA L. REV. 565 (1980). 
ally valid governmental motive-promoting childbirth. In its effort to support this assertion, HHS reads Regan ${ }^{143}$ far too broadly. Regan does not stand for the sweeping proposition that no constitutional violation occurs when federal funds are given only to those who support particular views that the government favors. Indeed, Regan itself rejected that readimg. ${ }^{144}$

The lobbying restriction in Regan is not aimed at the suppression of any one particular idea. ${ }^{145}$ Instead, the restriction reflects Congress' choice not to subsidize a particular activity-lobbying - with tax exemptions. The Code provision confers tax-exempt status on any group organized exclusively for "religious, charitable, scientific, testing for public safety, literary or educational purposes," provided that "no substantial part of [its] activities [involves] carrying on propaganda, or otherwise attempting, to influence legislation. ..."146 Congress was indifferent to the content of the lobbying that the charitable organizations would undertake. Groups qualifying for exemptions could have sought to advance an infinite variety of political and social agenda. No one point of view was singled out for suppression or penalty througli loss of exempt status; no particular speecl was restricted so that other ideas may flourisl. Lobbying per se is an activity, not a form of speech witl an inherent content: one can lobby on any topic. A refusal to subsidize lobbying thus does not infringe on the content of any particular speech, since all lobbying speech is subject to denial of funding. ${ }^{147}$

Unlike Regan's broad refusal to subsidize the entire range of lobbying activities, the regulations focus on speech with a disfavored content. HHS designed the regulations to linit the public's access to information about abortion options. The agency used extreine ineasures to prevent clinics from disseminating information about facilities that principally provide abortions. For exainple, under its regulations, a title $\mathrm{X}$ clinic that tells one of its clients about local abortion providers stands to lose its

143. 461 U.S. 540 (1983).

144. See supra note 124 and accompanying text.

145. The Regan statute excepted veterans groups from the lobbying restriction, a feature the Court upheld on the ground that veterans traditionally receive speeial preferences. Arguably, even the apparently neutral classifications in Regan are themselves viewpoint discriminatory as applied to groups lobbying against positions taken by veterans' groups because only veterans' groups can lobby with tax-deductible funds. For example, the Veterans of Foreign Wars can lobby against draft evader amnesty with tax-deductible donations from its members, but a nonprofit group advocating amnesty cannot. Note, Whose Voice Shall be Heard . ., 28 ST. LouIS U.L.J. 1017, 1028-30 (1984).

146. 26 U.S.C. $\S 501$ (c)(3) (1982).

147. This situation can be compared to one in which one point of view is singled out for suppression or penalty through loss of exempt status so that other ideas may flourish. See Buckley v. Valeo, 424 U.S. 1, $48-49$ (1976) ("[T] he concept that government may restrict the speech of some elements of our society in order to enhance the relative voice of others is wholly foreign to the First Amendment. ..."). 
title $\mathrm{X}$ funds. ${ }^{148}$ Thus a title $\mathrm{X}$ clinic preparing a list of area hospitals and prenatal facilities for its clients cannot include any information about any abortion facilities without risking the loss of a potentially crucial source of funding. A particular disfavored idea-that abortions are available in a particular place-is thus singled out for restriction. HHS is heading down the road against which Justice Harlan warned when lie predicted that censorship of particular words would be a convenient guise for the censorship of ideas. ${ }^{149}$

In addition to the content restriction on abortion speech, the regulations show that it is HHS's purpose to impose a constitutionally inpermissible viewpoint restriction. In its "[p]rohibition on activities that encourage, proinote or advocate abortion," $" 150$ HHS bars the title $X$ clinics from abortion-related lobbying, dues-paying, legal action, and publication. ${ }^{151}$ The aim clearly is to suppress the pro-choice view. By contrast, HHS seeks to promote the pro-life view by requiring tlie clinics to give clients materials about providers wlio will not perform abortions. The first ainendment does not tolerate such distortion of information. ${ }^{152}$

While both the restrictions on counseling and the ban on pro-choice lobbying suppress the pro-choice viewpoint, the lobbying restriction violates first amendinent values far inore. The pro-choice lobbying ban goes directly to the core of first amendnient values because it violates the premise tliat a fully informed legislature will, over the long liaul, proinote the public welfare better than an ill-informed one. "[S]peech is part of the legislative process itself; restriction of speech alters the denocratic process [and] conflicts witl the first ainendinent value of open debate." "153 Clainning that the threat to open debate is illusory because the clinics can lobby with non-title $\mathrm{X}$ funds ignores the substantial risk that inany clinics will find the separate facility scheine inpracticable and decline to lobby in order to ensure the ongoing receipt of their title $\mathrm{X}$ grants. ${ }^{154}$

The government's intent to alter the cliaracter of the public debate about reproductive health options for woinen is further evidenced by the HHS prohibition exclusively upon lobbying that proinotes abortions as a inetlod of family planning. The clinics can lobby for increased funding

148. 42 C.F.R. $\S 59.8(b)(3)$ (1988).

149. Cohen v. California, 403 U.S. 15, 26 (1971).

150. 42 C.F.R. $\$ 59.10$ (1988).

151. Id. It should not go unnoticed that a prohibition on the paying of dues to certain groups may impinge on first amendment associational rights as well. The prohibition on the use of legal action is also constitutionally suspect because the Court has held that bringing suits is itself a form of political expression entitled to first amendment benefits. NAACP v. Button, 371 U.S. 415 (1963).

152. See supra text accompanying notes 107-14.

153. J. NowAK, supra note 96 , at 837.

154. See infra notes $164-75$ and accompanyiug text. 
to title $\mathrm{X}$ projects, and they can lobby for a constitutional amendment forbidding abortions. They cannot lobby, however, for legislation that facihtates abortions in any way. One viewpoint is suppressed, but its opposite is permitted; ${ }^{155}$ pro-life groups receiving federal funds will not have their funding cut off. HHS's clear attempt to restrict the spread of the disfavored viewpomt thus violates the first amendment. ${ }^{156}$

In sum, there is no support for HHS's claim that the regulations are both content neutral and viewpoint neutral. Unlike the broad lobbying ban upheld in Regan, the regulations clearly discriminate on the basis of viewpoint because they restrict a particular point of view and impede the dissemination of certain information. The viewpoint suppressed is that abortion is a legitimate, available option that a pregnant woman may exercise. Excluding groups from government benefits "based on the desire to suppress a [disfavored] point of view" 157 is an unconstitutional governmental purpose.

\section{Penalty on the Clinics' Exercise of Free Speech: An Impermissible Effect}

The climics that choose to exercise their right to engage in speech about abortion lose more than just the title $X$ money they would have received. They are actually placed in a worse position than if there had been no title $X$ at all because they have grown dependent on title $X$ funds. Clinics have declared that if the regnlations go into effect, they will "be forced to choose between federal funding or the terminating of family planning services." 158 If they had never received title $X$ funds, they might have organized themselves differently and developed other sources of funding. Clinics "may reasonably [have] come to rely on past practice and justifiably regard a change as a deprivation, different in kind from a mere failure to provide a benefit."159

Furthermore, by subsidizing clinics that engage in counseling that excludes abortion as an option, the regulations effectively punish those

155. The First Circuit rejected as "factually untenable" HHS's argument that the regulations are not viewpoint-based, because they prohibit all advocacy concerning abortion, pro or con. Massachusetts v. Secretary of Health \& Human Servs., 873 F.2d 1528, 1546 (1st Cir. 1989).

156. As explained above, Regan does not countenance governmental suppression of content or viewpoints through funding choices. Content and viewpoint are irrelevant to the restrietions in Regan. Tax-exempt veterans groups "are entitled to receive tax-deductible contributions regardless of the content of any speech they may use, including lobbying." 461 U.S. at 548 (emphasis added). See supra text accompanying notes 145-47.

157. Cornelius v. NAACP Legal Defense and Educ. Fund, Inc., 473 U.S. 788, 812 (1985).

158. Massachusetts v. Secretary of Health and Human Servs., 873 F.2d 1528, 1551 (1st Cir. 1989) (Torruella, J., concurring in part and dissenting in part).

159. Kreimer, supra note 52, at 1362. Professor Kreimer also observes, "Losing a benefit previously provided [differs] from simply never having been provided the benefit in the first place." Id. at 1359. 
clinics that engage in the disfavored speech. The voice of the subsidized pro-life chinics is aniplified at the expense of the nonsubsidized clinics that speak about abortion. ${ }^{160}$

\section{Separate Facilities or a Total Funding Cut-off: A Choice Too Broad in Scope}

HHS insists that the separate facilities requirement ${ }^{161}$ ensures the constitutionality of the regulations. HHS contends that since the regulations "place no restrictions on the dissemination of information by health professionals about abortion, except in the context of the federally funded project[s]," no free speech rights are penalized. ${ }^{162}$ Health professionals can disseminate any information they choose about abortion outside the title $\mathrm{X}$ project, but may not provide information "discussing, promoting, or otherwise encouraging abortion" within the title $\mathrm{X}$ project. ${ }^{163}$

HHS's position that the separate facilities requirement ensures the constitutionality of the regulations does not withstand close analysis. The regulations contain a burdensoine requirement that abortion-related activities be physically and financially separate from the title $\mathrm{X}$ project. In this respect, they differ dramatically from the easily satisfied dual organization requirement in Regan. The Regan Court noted that " $[t]$ he IRS apparently requires ouly that the two groups be separately incorporated and keep records adequate to show that tax-deductible contributions are not used to pay for lobbying. This is not unduly burdensome." 164

When the Court considered the separate affiliate doctrine again in League of Women Voters, it noted in dicta that a public television station's editorializing affiliate "would be free, in the saine way that the charitable organization in [Regan] was free," to editorialize through its nonfederally funded affiliate without losing its federal grants for its other activities. ${ }^{165}$ It is not clear what the Court meant when it suggested that " 'affiliate' organizations . . . could then use the station facilities to edito-

160. See L. TRIBE, supra note 94 , at 782 ("[T] he very decision to subsidize one activity [may] entail[ a decision to penalize another."). Cf. Buckley v. Valeo, 424 U.S. 1, 48-49 (government cannot restrict some speech to enhance other speech).

161. See supra text accompanying notes $85-89$ for background on the separate affiliate doctrine laid out in Regan v. Taxation with Representation, 461 U.S. 540 (1983), and FCC v. League of Women Voters, 468 U.S. 364 (1984).

162. 53 Fed. Reg. 2935 (1988).

163. Id. at 2936.

164. 461 U.S. at 544-45 n.6. Justice Blackmun's concurrence in Regan puts considerable weight on the fact that the IRS "goes no further" than requiring separate bookkeeping, an arrangement he finds acceptable because it does not amount to an infringement on the organization's right to speak. Id. at 553 .

165. 468 U.S. at 400 . 
rialize with nonfederal funds . . ."166 The Court was not suggesting that PBS stations which wanted to editorialize would have to set up whole new television broadcasting facilities solely for that purpose. Such a proposal would violate Regan's requirement that the establishinent and maimtenance of the separate facility not be "unduly burdensome."

By contrast, the expense to the clinics necessary to satisfy the physical separation requireinent far exceeds the separate bookkeeping sclieine envisioned in Regan. ${ }^{167}$ If a title X clinic wislies to continue abortion counseling, it inay do so, but only if it incurs the cost of inaintaining the separate facilities that the regulations require. Thus, the separate facilities requirement again punisles clinics for engaging in the disfavored speecl.

The clinics stand in the saine position as the hypotletical Medicaid recipient in Harris, who would lose her entire Medicaid entitleinent because she obtained an abortion with lier own funds, and the unemployment claimant in Sherbert, who lost all her uneniploynient benefits because slie refused to work on Saturdays. ${ }^{168}$ The clinics will lose all federal subsidies if they engage in the prohibited conduct-speech about abortion. Just as the Medicaid recipient spent her own nioney on the abortion, the clinics may spend their own nioney to prepare brocluures and to train counselors about abortion providers. As long as she dips into her own funds to pay for lier abortion, the welfare notler in Harris does not risk a total denial of her governnient benefits. No such option is available to the clinics. Using nontitle $X$ funds to engage in the prohibited conduct does not save the clinic froin a denial of federal support. ${ }^{169}$

The regulations' separate affiliate requirenent is defective on otler grounds as well. Normally, regulations that iniplicate first aniendinent freedoins inust be precisely drafted to pass constitutional scrutiny. ${ }^{170}$ The HHS regulations, however, do not provide any clear guidelines as to what HHS ineans when it says the regulations inerely restrict what an organization may do "within the confines" of the title X project. ${ }^{171}$ If an arm of the clinic is providing counseling and referral, it nuust liave

166. Id. (emphasis added).

167. The clinics will lose their benefits even if all the money they spend on abortion-related activities comes from their paying clients. See supra text accompanying note 34, explaining how the new regulations redefine "project funds" to include private fee income; see also Massachusetts v. Secretary of Health and Human Servs., 873 F.2d 1528, 1545 n.4 (1st Cir. 1989) (HHS regulations' separate facilities requirements are "significantly more onerous than the purely paperwork requirements at issue in Regan.").

168. See supra notes 129-32 and accompanying text.

169. See supra text accompanying notes 34 and 167.

170. Village of Hoffman Estates v. The Flipside, 455 U.S. 489, 497-99 (1982); see also NAACP v. Button, 371 U.S. 415, 438 (1968) (requiring "precision of regulation" when free expression is involved, while upholding NAACP advocacy activities).

171. 53 Fed. Reg. 2935 (1988). 
"objective integrity and independence from prohibited activities." 172 The Secretary has broad discretion to decide whether the requirement is satisfied "based on a review of [the] facts and circumstances."173 Factors in the Secretary's review include the existence of separate accounting records, the degree of physical separation from facilities in which prohibited activities occur, the existence of separate personnel, and the extent that signs and other kinds of identification of the title $X$ project are present and inaterial promoting abortion is absent. ${ }^{174}$ These criteria offer the Secretary so much discretion that arbitrary and selective enforcement is a real possibility. The clinics, lacking any clear guidance by HHS on how much separation is enough, may well overspend in their efforts to comply. ${ }^{175}$ The vagueness of the separate facilities requirement actually increases the financial burden, and hence the penalty, that the climics suffer.

\section{CONCLUSTON}

In short, the regulatory scheme fails in part because its means (total deinal) are too broad, not because its end (promoting childbirth) is illegitimate. If it would be unconstitutional to remove a woman from the welfare rolls because she had an abortion, or because she gave a speech against the government, it should be unconstitutional to remove a clinnc from the title $\mathrm{X}$ rolls because it facihtates abortions, or because it advances pro-choice positions in its lobbying.

The abortion issue is one on which thoughtful people can vehemently disagree. But both sides of the abortion debate overlook interests they have in common-an interest in stable, settled expectations of civil rights, and an interest in a governinent that neither acts nor appears to act lawlessly. The regulations undeniably threaten these interests and should alarm men and woinen who champion the rights of the fetus as well as those who advocate the rights of women to make their choice. HHS is pushing vigorously to promote its own idea of progress on the right-to-life front without considering how its actions will unsettle the clinics', their clients', and the public's belief in the right to speak and the right to have an abortion.

When governinent ignores the implications of what it is doing and acts in unprincipled ways, it threatens the long-term institutional stability of the system itself. For instance, even HHS would probably concede

172. 42 C.F.R. 59.9 (1988).

173. Id.

174. Id.

175. Cf. Keyishian v. Board of Regents, 385 U.S. 589, 604 (1967) (noting danger that one will "steer far wider of the unlawful zone" in the face of vague regulations) (quoting Speiser v. Randall, 357 U.S. 513, 526 (1958)). 
that a scheme according certain tax deductions only to newspapers which agreed not to editorialize for legal abortions would be unconstitutional. ${ }^{176}$ Yet HHS's arguments offer no way to distinguish that scheme from the regulations. The public perception that the government has declared war on climics which seek only to engage in constitutionally protected behavior will, if only in the long term, undermine the public's confidence that the executive branch will respect the Constitution as interpreted by the courts.

If the Supreme Court were to uphold these regulations to advance the narrow objectives of a bare majority of the Court on the abortion issue, it will have upheld, to a previously unseen degree, government's ability to coerce choice and manipulate information.

176. The example is a variation of one offered in Benshoof, supra note 10, at 1922. 